University of Nebraska - Lincoln

DigitalCommons@University of Nebraska - Lincoln

USDA Forest Service / UNL Faculty Publications U.S. Department of Agriculture: Forest Service -National Agroforestry Center

2013

\title{
Modeling harvest and biomass removal effects on the forest carbon balance of the Midwest, USA
}

\author{
Scott D. Peckham \\ University of Wisconsin, sdpeckha@wisc.edu \\ Stith T. Gower \\ University of Wisconsin, stgower@facstaff.wisc.edu \\ Charles H. Perry \\ USDA Forest Service \\ Barry T. Wilson \\ USDA Forest Service \\ Kirk M. Stueve \\ USDA Forest Service, kirk.stueve@ndsu.edu
}

Follow this and additional works at: https://digitalcommons.unl.edu/usdafsfacpub

Peckham, Scott D.; Gower, Stith T.; Perry, Charles H.; Wilson, Barry T.; and Stueve, Kirk M., "Modeling harvest and biomass removal effects on the forest carbon balance of the Midwest, USA" (2013). USDA Forest Service / UNL Faculty Publications. 241.

https://digitalcommons.unl.edu/usdafsfacpub/241

This Article is brought to you for free and open access by the U.S. Department of Agriculture: Forest Service -National Agroforestry Center at DigitalCommons@University of Nebraska - Lincoln. It has been accepted for inclusion in USDA Forest Service / UNL Faculty Publications by an authorized administrator of DigitalCommons@University of Nebraska - Lincoln. 


\title{
Modeling harvest and biomass removal effects on the forest carbon balance of the Midwest, USA
}

\author{
Scott D. Peckham ${ }^{a, 1, *}$, Stith T. Gower ${ }^{a}$, Charles H. Perry ${ }^{b}$, \\ Barry T. Wilson ${ }^{b}$, Kirk M. Stueve ${ }^{b, 2}$ \\ a Department of Forest and Wildlife Ecology, University of Wisconsin, 1630 Linden Drive, Madison, WI 53706, USA \\ ${ }^{\mathrm{b}}$ Northern Research Station, USDA Forest Service, 1992 Folwell Avenue, St. Paul, MN 55108, USA
}

\section{A R T I C L E I N F O}

Article history:

Received 7 February 2012

Received in revised form

5 September 2012

Accepted 5 September 2012

Published on line 6 November 2012

\section{Keywords:}

Net ecosystem production

Forest carbon management

Ecosystem modeling

Biome-BGC

Biomass harvesting

Great Lakes forests

Sustainable forest management

Bioenergy

Harvest

\begin{abstract}
A B S T R A C T
The objective of this study was to use an ecosystem process model, Biome-BGC, to explore the effects of different harvest scenarios on major components of the carbon budget of $205,000 \mathrm{~km}^{2}$ of temperate forest in the Upper Midwest region of the U.S. We simulated seven harvest scenarios varying the (i) amount of harvest residue retained, (ii) total harvest area, and (iii) harvest type (clear-cut and selective) to assess the potential impacts on net biome production (NBP), net primary production (NPP), and total vegetation carbon. NBP was positive (C sink) in year 1 (2004) and generally decreased over the 50-year simulation period. More intensive management scenarios, those with a high percentage of clear-cut or a doubling of harvest area, decreased average NBP by a maximum of $58 \%$ and vegetation C by a maximum of $29 \%$ compared to the current harvest regime (base scenario), while less intensive harvest scenarios (low clear-cut or low area harvested) increased NBP. Yearly mean NPP changed less than $3 \%$ under the different scenarios. Vegetation carbon increased in all scenarios by at least $12 \%$, except the two most intensive harvest scenarios, where vegetation carbon decreased by more than $8 \%$. Varying the amount of harvest residue retention had a more profound effect on NBP than on vegetation C. Removing additional residue resulted in greater NBP over the 50 -year period compared to the base simulation. Results from the seven model simulations suggest that managing for carbon storage and carbon sequestration are not mutually exclusive in Midwest forests.
\end{abstract}

C 2012 Elsevier Ltd. All rights reserved.

\section{Introduction}

The forests of the Midwest region of the United States are both an important source of fiber for wood and paper products and a carbon sink for atmospheric carbon dioxide (Goodale et al., 2002; Crevoisier et al., 2010; Ryan et al., 2010). Minnesota, Wisconsin, and Michigan, contain the majority of the forests in the Midwest, with forests covering approximately $50 \%$ of each of these states (Smith et al., 2004). The Midwest forests produce more than $20 \mathrm{Mm}^{3}$ of pulpwood annually, or $14 \%$ of pulp for the paper industry in the U.S. (USDA, 2001), and they produce $>250 \mathrm{Mm}^{3}$ of wood, or $>50 \%$ of the supply for the nation's composite wood products. These same forests also provide numerous other ecosystem services in addition to wood production, such as carbon sequestration, habitat for game and non-game species, and soil and water protection. The forests of the Midwest region (see Section 2 for description) cover more than 20 million hectares, include both public and private ownership, exist in tracts from small

\footnotetext{
* Corresponding author. Tel.: +1 608265 5628; fax: +1 6082629922.

E-mail addresses: sdpeckha@wisc.edu, sdpeckha@carbonmodel.org (S.D. Peckham).

${ }^{1}$ Present address: Department of Botany, University of Wyoming, 1000 E. University Avenue, Laramie, WY 82071, USA.

2 Present address: Department of Geosciences, North Dakota State University, Stevens Hall 218, Fargo, ND 58108, USA. 1462-9011/\$ - see front matter (C) 2012 Elsevier Ltd. All rights reserved. http://dx.doi.org/10.1016/j.envsci.2012.09.006
} 
farm woodlots to the expansive wilderness of northern Minnesota, and have been utilized by humans in most areas since the 1800s. The forests' tree species composition is diverse ranging from central hardwoods in the south, to coldtemperate northern hardwoods and conifer forests, including transitional boreal forests in the far north. In summary, the past and current use(s) of Midwest forests are diverse and sometimes competing.

These same forests are also a potential source for feedstock for bioenergy as the U.S. attempts to develop sustainable bioenergy systems that will reduce national dependence on foreign fossil fuel (Perlack et al., 2005). In anticipation of greater demand for woody biomass, forest managers and policy makers are developing harvest guidelines to ensure sustainable forest management practices. Options to increase woody biomass harvest include increased removal of residue (i.e. cull trees, tops of trees etc.) normally left in the forests, increased harvest frequency, and increased harvested area. However, there are extremely few long-term field studies that can be used to guide management and policy decisions. It is unclear how greater biomass utilization of the forest resource will affect the long-term soil carbon storage, nutrient availability, and productivity (i.e. carbon sequestration) of future forests. It is imperative to quantify the effects of harvest regimes on carbon pools with fast to moderate residence times (e.g. vegetation) and especially carbon pools with slow residence times (e.g. mineral soil). Recent studies have shown that forest disturbance is an important driver of ecosystem C balance (Euskirchen et al., 2002; Thornton et al., 2002; Law et al., 2004; Bond-Lamberty et al., 2007b; Amiro et al., 2010; Peckham et al., 2012).

Ecosystem process models allow scientists to simulate effects of different management practices on forest sustainability, growth, and carbon dynamics at scales ranging from stand to region. Unlike empirical growth and yield models, process-based ecosystem models simulate water, nitrogen, and carbon cycles, and their interactions, and they account for soil and detritus carbon dynamics (Peckham and Gower, 2011). Modeling the $\mathrm{C}$ balance of a heterogeneous forestscape, such as the Upper Midwest, is challenging because the spatially and temporally explicit disturbance history is not well documented. Hence, most modeling studies covering this region do not account for disturbance history in $\mathrm{C}$ balance or net ecosystem production (NEP) (e.g. Lu and Zhuang, 2010; Wang et al., 2011). However, previous modeling studies have shown that management regime is the most important determinant of forest $C$ balance (Euskirchen et al., 2002), for individual forest stands (Peckham and Gower, 2011), and at the regional level (Peckham et al., 2012). Landscape-level effects of management choices on the future forest $\mathrm{C}$ balance over the Midwest are poorly understood.

The objective of this study was to use the ecosystem process model Biome-BGC to simulate the carbon balance of the Midwest deciduous and coniferous forests subjected to different harvest scenarios. We used historic (1800s to early 1900s) to near present-day (2004) harvest and management records to simulate initial harvests and estimate forest vegetation carbon (vegC), net primary production (NPP), net biome production (NBP, defined as NEP integrated over space and time (Chapin et al., 2006), and to examine historic patterns and spin the model up to present-day conditions. Then, we simulated 50-year future management scenarios that varied the total harvest area, the clear-cut and selective harvest proportions (0.0-1.0), and three harvest residue retention rates $(15,25$, and $35 \%)$. Due to the large number of simulations and the temporal and spatial scale, we could not do a complete factorial set of simulations. Instead we selected seven simulations that span the range of conditions and hypothesized responses. Also, the seven scenarios were selected to provide a range of scenarios to elucidate the trade-offs between two competing forest carbon management objectives: carbon storage (i.e. total vegC) versus carbon sequestration (i.e. NBP). To assess potential management effects on forest ecosystem $C$ dynamics, the model output of stand age structure, vegC, NPP and NBP were compared to a base scenario that continued the current harvest regime. We hypothesized that increased biomass removal would increase NBP but decrease $C$ storage in vegetation and that increased removal of harvest residues would decrease NPP. It is important to note that we only consider the fluxes of $C$ in the forest ecosystem explicitly simulated by Biome-BGC. Carbon emission and storage resulting from the use of harvested biomass has important consequences on total carbon sequestration and is the subject of a companion study (Peckham and Gower, accepted).

\section{Methods}

\subsection{Study area}

The simulations were run for the forested areas within the boundary of the Mid-continent intensive (MCI) study area of the North American Carbon Program (http://www.nacarbon. org/nacp/mci.html). This area includes the states of Minnesota, Wisconsin, Iowa, Illinois, and portions of North Dakota, South Dakota, Nebraska, Kansas, Missouri, Indiana, and Michigan (Fig. 1). The MCI region encompasses 125 Mha of forest, agriculture, and urban landscapes, of which forests comprise $18 \%$ of the region. The dominant forest types are deciduous broad-leaf (hardwoods) and evergreen needle-leaf forests (conifers) in both uplands and lowlands. The largest forest regions occur in the northern Michigan, Wisconsin, and Minnesota, while smaller regions but exist in northern Missouri and southern Illinois. The topography is generally low relief (Potter et al., 2007), with some rolling hills and deep river valleys. Climate ranges from long, cold winters and a short growing season ( $<120$ days) in the northern region to mild winters and long ( $>180$ days) growing season in the southern region. Based on the climate data used to drive the model (1955-2004), air temperatures averaged -2.9 and $28.3^{\circ} \mathrm{C}$ in January and July, respectively. Precipitation is primarily rain from May to October and averages $803 \mathrm{~mm} / \mathrm{yr}$. Fig. 1 summarizes annual air temperature and precipitation for the region.

\subsection{Biome-BGC}

We used Biome-BGC, an ecosystem process model that simulates carbon $(C)$, nitrogen $(N)$, and water cycles, and their 

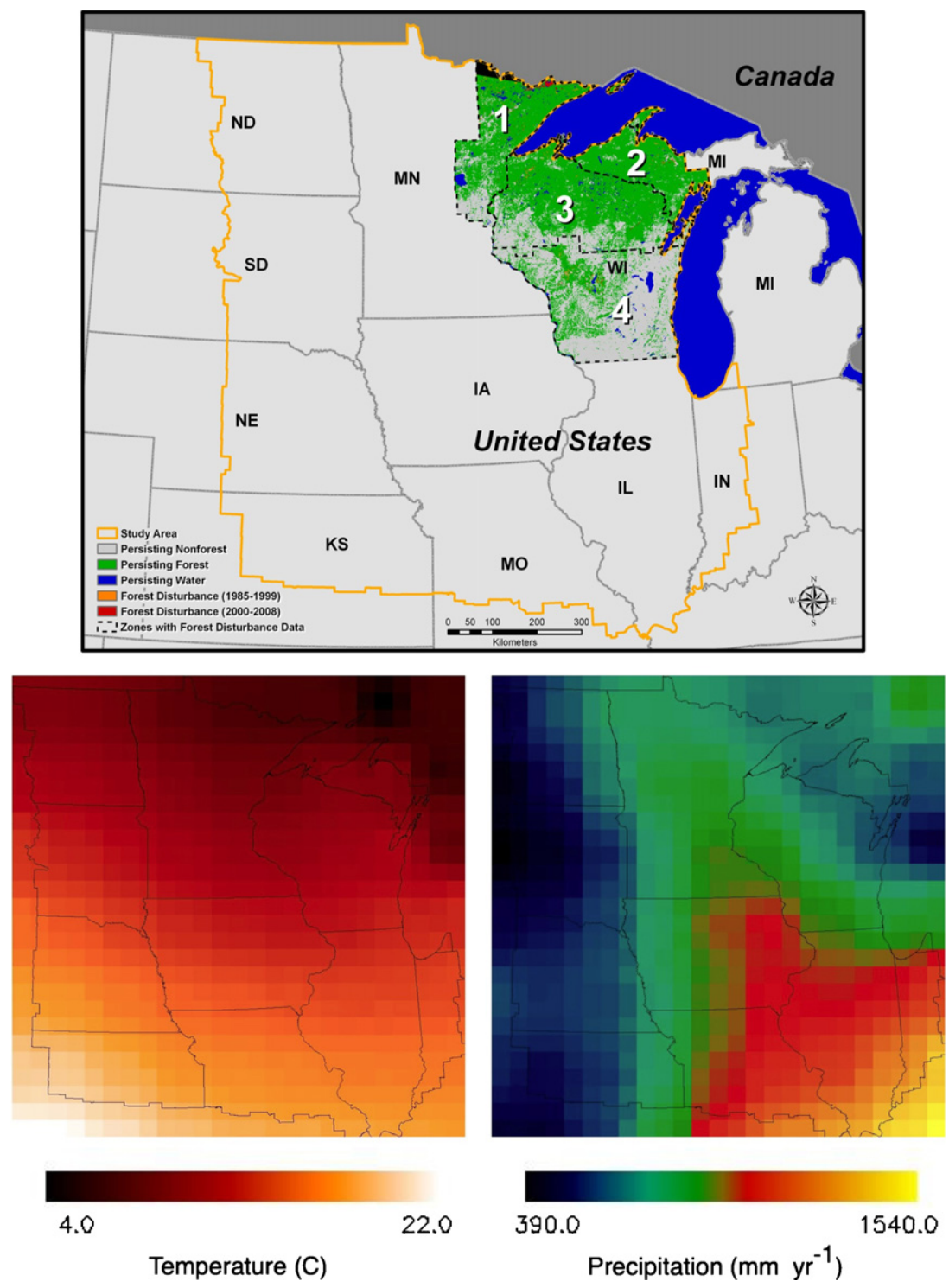

Fig. 1 - Coverage of VCTw data in the study area and regions (1-4) used to calculate disturbance statistics (top) for the 50-year management scenarios and summary maps of mean annual temperature and precipitation (bottom) computed from the NCEP climate data.

Source: Stueve et al. (2011).

interactions, but we only summarized the $C$ budgets. Biome$B G C$ requires daily minimum and maximum air temperature, total solar irradiance, average vapor pressure deficit (VPD), and total precipitation. Physiological processes are calculated for both sunlit and shaded portions of the plant canopy. Photosynthesis per unit leaf area is simulated using the Farquhar biochemical model (Farquhar et al., 1980) and stomatal conductance is calculated as a function of radiation, VPD, leaf water potential, and minimum nighttime temperature (Running and Coughlan, 1988). Both plants and microbes compete for a single pool of available mineral soil N. Complete model logic and processes have been described in detail previously (Running and Coughlan, 1988; Running and Gower, 1991; Kimball et al., 1997; White et al., 2000; Thornton et al., 2002). The version used in this study simulates large regions
(Bond-Lamberty et al., 2007b; Bond-Lamberty et al., 2009; Peckham et al., 2012), disturbance (Bond-Lamberty et al., 2007b; Bond-Lamberty et al., 2009; Peckham and Gower, 2011; Peckham et al., 2012), and includes improvements for flooded soils (Bond-Lamberty et al., 2007a). Disturbance (forest harvest in this study) was simulated in Biome-BGC using the same modifications to $\mathrm{C}$ and $\mathrm{N}$ pools as described in detail previously (Thornton et al., 2002; Peckham and Gower, 2011).

We have evaluated Biome-BGC output to field measurements and reported reasonable agreement. We observed good agreement between measured and simulated NPP for two forest types in northern WI (Peckham and Gower, 2011), measured and modeled NPP for well- and poorly drained wildfire chronosequences (Bond-Lamberty et al., 2007a), and measured and modeled soil C accumulation, NPP and NEP for 
northern hardwood chronosequence (Peckham and Gower, 2011; Peckham et al., 2012).

The near present-day (2004) conditions in Biome-BGC were estimated using a two-step initialization procedure. First, a spin-up or model self-initialization (Thornton and Rosenbloom, 2005) was run using 25 years of historical meteorological data (1948-1973) (see below for specific details) and preindustrial estimates of atmospheric carbon dioxide $\left(\mathrm{CO}_{2}\right)$ concentration and nitrogen deposition (Ndep), $280 \mathrm{ppm}$ and $0.001 \mathrm{~kg} / \mathrm{m}^{2}$, respectively. Following spin-up, we simulated the 1800-2004 period to estimate near-present day model C and N pool values and initialize all of the harvest simulations in this study. Much of the MCI's forest landscape was clear-cut in the 19th century; therefore a historic disturbance data set was constructed to simulate past land use history between 1800 and 2004 (see Section 2.4 for detailed description). Atmospheric $\mathrm{CO}_{2}$ concentration and atmospheric nitrogen deposition (Ndep) varied from pre-industrial (1800) estimates up to nearpresent day (1998) levels.

\subsection{Model input data}

The spatial data required for each grid cell to complete the model simulations are summarized in Table 1 and briefly discussed below. All data were re-projected and resampled to a common modeling grid $\left(1 \mathrm{~km}^{2}\right.$ cells) and sub-setted to the MCI region (Fig. 1). Surface albedo was estimated using the MODIS MOD 43B product (http://www-modis.bu.edu/brdf/ userguide/albedo.html). Several image tiles from a July composite image in 2006 were selected which covered the study area. Daily climate data from the NCEP reanalysis project (http://www.esrl.noaa.gov/psd/data/gridded/reanalysis/) were used to drive the model. The climate data from 1948-2004 were resampled to a $50 \mathrm{~km}^{2}$ resolution grid (climate data only) that matched the spatial extent of the common modeling region following techniques used in previous modeling studies (Bond-Lamberty et al., 2007b; Bond-Lamberty et al., 2009; Peckham et al., 2012). This resolution captures the broad climate patterns in the region (Fig. 1), but may not capture local climactic gradients (i.e. areas within close proximity to the Great Lakes). An additional challenge is the available climate data do not cover the entire time period of interest. Therefore, we elected to focus solely on harvest effects and remove the effects of inter-annual climate effects on the disturbance (harvest) response in each grid cell by using a climate ensembling method (Thornton et al., 2002). BiomeBGC outputs are an average of 50 individual simulations, each simulation beginning with a different year in the climate record. Elevation was determined from the National Elevation Dataset (http://ned.usgs.gov/), the $30 \mathrm{~m}$ data were aggregated to the modeling grid using the focal mean. Soil depth and percentages of sand, silt, and clay were obtained from STATSGO2 (http://soils.usda.gov/survey/geography/statsgo/) and gridded to match the modeling region. Soil water inflow and outflow parameters were derived from the drainage classes (excessive, well, moderate, poor) in STATSGO2, following Bond-Lamberty et al. (2007b). Atmospheric carbon dioxide concentrations were obtained from Etheridge et al., 1998. The Ndep data (1987-1994) were obtained from the Oak Ridge National Laboratory (http://daac.ornl.gov/CLIMATE/ guides/nitrogen_deposition.html). Forest type and stand age were determined using raster data created from U.S. Forest Service forest inventory and analysis (FIA) plot data (Wilson, 2009 , ongoing). The $250 \mathrm{~m}$ resolution data was aggregated to the $1 \mathrm{~km}^{2}$ modeling grid using the majority. Due to lack of explicit history for each location, we assumed in this study, stand age was approximately the time since last disturbance. The ecophysiological constants for each forest type were derived and evaluated in a previous study (Peckham et al., 2012), and are listed for the simulated FIA forest types in Table 2. Mean values provided by White et al. (2000) for evergreen needle-leaf and deciduous broad-leaf forest types were used as appropriate, with the exception of specific leaf area and leaf C:N (Peckham et al., 2012) (Table 2).

\subsection{Disturbance history}

The current carbon balance of a forest, or forest region is strongly influenced by its past disturbance history (Gower, 2003; Amiro et al., 2010; Peckham et al., 2012); however, re-

\section{Table 1 - Summary of spatial data characteristics used in Biome-BGC simulations.}

\begin{tabular}{llcc} 
Data description & Temporal resolution & Native spatial resolution & Sensor/collection \\
\hline Site attribute & & & $30 \mathrm{~m}$ \\
Elevation $^{1}$ & - & $30 \mathrm{~m}$ & NED \\
Forest disturbance $^{2}$ & $\sim 2004$ & $250 \mathrm{~m}$ & NAFD VCTw \\
Forest type $^{3}$ & $\sim 2004$ & - & FIA \\
Soil-\% sand $^{4}$ & - & - & STATSGO \\
Soil-\% silt $^{4}$ & - & - & STATSGO \\
Soil-\% clay $^{4}$ & - & $500 \mathrm{~m}$ & STATSGO \\
Surface albedo $^{5}$ & July (2006) & $250 \mathrm{~m}$ & MODIS \\
Stand age $^{3}$ & $\sim 2004$ & - & FIA \\
Soil-drainage $^{4}$ & - & & STATSGO \\
Climate $^{\text {Maximum temperature }}{ }^{6}$ & & $\sim 2.5^{\circ}$ & \\
Minimum temperature $^{6}$ & Daily, 1948-2008 & $\sim 25^{\circ}$ & NCEP reanalysis \\
Precipitation $^{6}$ & Daily, 1948-2008 & $\sim 2.5^{\circ}$ & NCEP reanalysis \\
Shortwave radiation $^{6}$ & Daily, 1948-2008 & $\sim 2.5^{\circ}$ & NCEP reanalysis \\
Relative humidity $^{6}$ & Daily, 1948-2008 & $\sim 2.5^{\circ}$ & NCEP reanalysis \\
\hline Superscript denotes the data source. 1 & Daily, 1948-2008 & NCEP reanalysis \\
\hline
\end{tabular}


Table 2 - Summary of forest type groups and values used for leaf C:N and canopy average specific leaf area (SLA) in the Biome-BGC ecophysiological parameter set.

\begin{tabular}{lcc} 
Forest type group & Leaf C:N & SLA $\left(\mathrm{m}^{2} \mathrm{~kg}^{-1} \mathrm{C}\right)$ \\
\hline Pine & 36.6 & 9.3 \\
Spruce/fir & 43.4 & 8.2 \\
Loblolly & 42.0 & 8.2 \\
Eastern softwoods & 30.5 & 6.0 \\
Ponderosa group & 42.0 & 2.2 \\
Exotic softwood & 34.1 & 6.8 \\
Oak & 24.8 & 28.8 \\
Oak/gum/cypress & 25.0 & 32.0 \\
Elm/Ash & 22.3 & 36.6 \\
Maple & 25.3 & 41.3 \\
Aspen & 25.7 & 24.2 \\
Exotic hardwood & 24.0 & 32.0 \\
\hline
\end{tabular}

creating a comprehensive pre- and post-settlement disturbance spatial data layer for the MCI region is extremely challenging, and perhaps impossible (Whitney, 1994). The objective of this study was to examine the effects of different harvest scenarios on forest $C$ dynamics using near presentday conditions as a starting point; the objective was not to simulate historic C dynamics. Therefore, the approach outlined below is reasonable to develop initial historic disturbance history that can be used to run the model up to nearpresent day conditions. We searched the literature for general observations of forest clearing rates, timing, and intensity for the $\mathrm{MCI}$ region from 1800 to the present. Biome-BGC does not simulate landcover conversion (i.e. forest to agriculture or vice versa), so we only simulated the current forested area and assumed those areas now forested have been so since the beginning of the simulation. We assumed that prior to 1800 the forest was intact, primary, only subject to natural disturbances, and that NBP was in relative equilibrium with the atmosphere (i.e. C balance approximately zero). These assumptions are consistent with historical accounts in the region (Williams, 1989; Whitney, 1994). Wind and fire disturbance are rare (>1000 year return interval) in hardwood forests, but more frequent (50-200 year return interval) in conifers (Frelich, 1995). Mortality fractions in Biome-BGC were set to reflect these disturbances using data available from the region (Whitney, 1994; Frelich, 1995; Cleland et al., 2004). Starting with estimates of the current stand age (2004, Fig. 2) for each cell and working backwards, we created a general disturbance regime and simulated it over 1800-2004 to estimate current model $\mathrm{C}$ pools for each grid cell. For the model initialization simulation, we assumed all current stands originated from a harvest, and each location was harvested at least once, with the exception of areas within the Boundary Waters Canoe Area (MN), Porcupine Mountains (MI), and Sylvania Lakes (MI) Wilderness areas, which are the only remaining old-growth forests of significant area in this region (Frelich, 1995). We simulated two types of harvest, clear-cut and selective (or partial-cut). Clear-cut harvest assumed $100 \%$ removal of trees and vegetation growth was subsequently restarted. Selective harvests were assumed to remove $25 \%$ of the canopy area and biomass. The proportion of selective harvest (of the total area harvested annually) was assumed to increase linearly from 0.0 in 1930 to 0.75 in 2004, reflecting the increasing use of selective harvest from its adoption in the

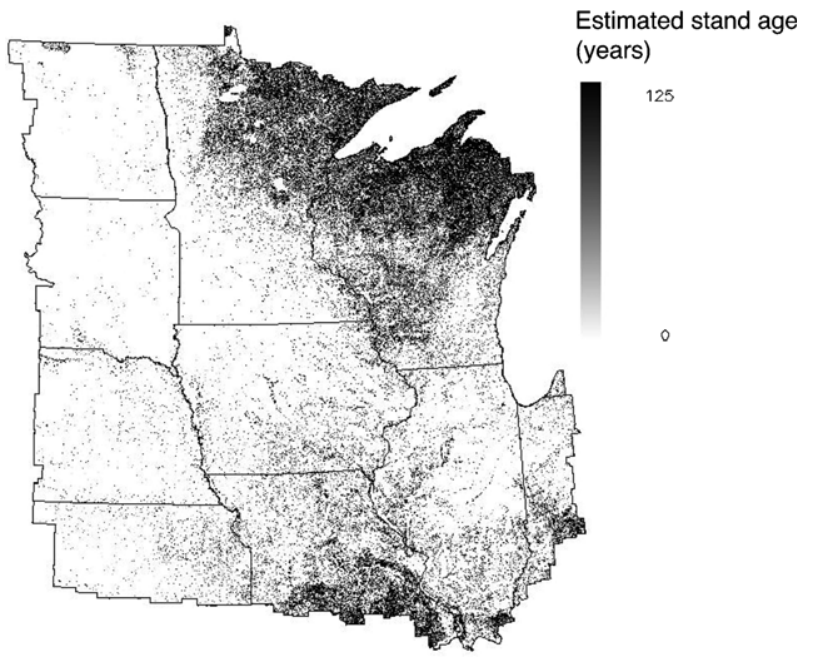

Fig. 2 - Estimated stand age for the MCI region (2004), at simulation start.

Source: Data shown are estimates provided by Wilson, 2009 resampled to a $1-\mathrm{km}^{2}$ spatial resolution, and were used to help determine harvest locations in each management scenario.

early- to mid-1900s (Gronewold et al., 2010) to present day (Smith et al., 2010). Forest clearing began in southern portions of the study area around 1800 (Birdsey et al., 2006) and in the northern portions during the late-1800s in (Steyaert and Knox, 2008). Following the 'initial cutover', we assumed forests regenerated for at least 70 years before any new harvest occurred, which we randomly assigned spatially to a pixel. The end result was an initialization spatial data set (modeled $C$ pools and fluxes) for each forest pixel with a simulated stand age that exactly matched FIA-derived estimates (resampled to the modeling grid) around 2004 (mid-point of the FIA analysis period used to create the FIA stand age raster dataset).

\subsection{Management scenarios}

The management scenarios simulated in this study were selected to evaluate the effects of harvest intensity (clearcut vs. selection), removal of harvest residues, and total annual harvest area on the $\mathrm{C}$ fluxes in the MCI region. Based on regional statistics, we consider our 'base' simulation to represent current harvest levels. Over the entire study region, annual harvest area averaged $1.7 \%$ per year (2001-2005), and clear-cut and selective harvests comprised 25 and $75 \%$ of total harvest, respectively (Smith et al., 2010). The amount of harvest residue left on site (as a percentage of total harvest) was obtained from a previous modeling study in the region (Peckham et al., 2012) and set to $25 \%$ for the base. We chose six additional scenarios (Table 3 ) to simulate over the MCI region that involved only a single modification to the base scenario. These scenarios either increased or decreased the harvest area, percentage of clear-cut harvest type, or amount of harvest residue left. The scenarios may not be realistic for all conditions or forest types, but they are only intended to provide a broad array of biomass removal scenarios to elucidate regional forest $C$ dynamics. 
Table 3 - Details of the management scenarios.

\begin{tabular}{lcccc} 
Scenario & $\begin{array}{c}\text { Harvest (as a fraction } \\
\text { current rate) }\end{array}$ & $\begin{array}{c}\text { Clear-cut } \\
\text { (\% of total) }\end{array}$ & $\begin{array}{c}\text { Selective-cut } \\
\text { (\% of total) }\end{array}$ & $\begin{array}{c}\text { Residue retention } \\
\text { (\% of harvest biomass) }\end{array}$ \\
\hline Base (B) & 1.0 & 25 & 75 & 25 \\
Base + low retention (BRL) & 1.0 & 25 & 75 & 15 \\
Base + high retention (BRH) & 1.0 & 25 & 75 & 35 \\
Selective high (SH) & 1.0 & 0 & 100 & 25 \\
Clear-cut high (CH) & 1.0 & 25 & 50 & 25 \\
Area high (AH) & 2.0 & 25 & 75 & 25 \\
Area low (AL) & 0.5 & 75 & 25 \\
\hline
\end{tabular}

\subsection{Determination of harvested area}

The annual harvest rates used for the scenarios described above were computed for sub-regions (Fig. 1) of the study area because the MCI region spans multiple forest ownership types (i.e. federal, state, county, private non-industrial, etc.) and covers a large and diverse geographical area. Current levels of forest harvest were determined for the selected regions using two primary data sources: (1) improved vegetation change tracker (VCTw), a forest disturbance dataset derived from long time-series of Landsat data (Stueve et al., 2011), and (2) regional statistics published by the U.S. Forest Service (Smith et al., 2010). First, the rate (an estimate for return-interval) of stand-replacing disturbance (although imperfect, assumed here a result of clear-cut harvesting practices) was calculated from the VCTw data for the major forest regions in the study area (see Fig. 1 for VCTw data and region deliniation). These four regions contain over $50 \%$ of the forests in the study area and were chosen based on data availability, state boundaries, and major shifts in forest ecosystem type (i.e. Northern and Southern Wisconsin, regions 3 and 4). The area of selective harvest for each region was then computed using the estimate from the VCTw data and the ratio of selective to clear-cut harvests in the greater study area (Smith et al., 2010). Table 4 summarizes the region-specific harvest rates used to implement the management scenarios. We assumed infrequent disturbance such as wind, fire, tornado, and insects were captured in the annual fire and mortality fractions in the Biome-BGC parameter set.

Although harvest locations were chosen randomly, FIA raster data describing current stand age (described above) were used to constrain future harvest locations (i.e. only harvesting a stand once after it was $>60$ years of age). Although likely not applicable for all forest types, this constraint was chosen as the annual harvest rate of $1.7 \%$ is

\begin{tabular}{|c|c|c|c|}
\hline Region & Clear-cut & Selective & Total \\
\hline 1 & 0.41 & 1.23 & 1.64 \\
\hline 2 & 0.22 & 0.66 & 0.88 \\
\hline 3 & 0.45 & 1.36 & 1.81 \\
\hline 4 & 0.39 & 1.17 & 1.56 \\
\hline Portions outside of $1-4$ & 0.43 & 1.27 & 1.70 \\
\hline
\end{tabular}

Source: See Fig. 1 for region delineations and Section 2 for a detailed description how these values were estimated. equivalent to approximately a 60-year harvest return interval. A more species- and region-specific set of constraints would improve model estimates. Our random selection of harvest location does not account for logistical, spatial, or economic considerations that likely determine this process, but could be incorporated into future analyses when data become available.

\subsection{Model outputs and interpretation of results}

Biome-BGC outputs of vegetation C, NPP, NEP, and NBP were reported annually for the seven management scenarios. Harvest scenario simulations were compared to the base (B) simulation. Annual rates of change, or departure from the base were reported in $\mathrm{g} \mathrm{C} \mathrm{m}^{-2} \mathrm{yr}^{-1}$ or as a percentage change from initial conditions. Although we parameterized the model to simulate the FIA forest types described above, the results were summarized by deciduous broad-leaf (hardwoods) and evergreen needle-leaf (conifer) forests.

No formal statistics were performed on the model results because the sample size is so large ( $n=206,000$ cells) that all treatment effects were significant (i.e. standard errors were less than $0.5 \mathrm{~g} \mathrm{C} \mathrm{m}^{-2} \mathrm{yr}^{-1}$ ). Therefore, we elected to express results relative to the base scenario.

\section{Results}

\subsection{Model initialization}

Simulated stand age (time since last simulated harvest) at each modeled location in the MCI region matched FIA-derived stand age estimates for 2004. Stand age in the region averaged 48 years in 2004. At the end of the initialization run (2004) of the 206,000 individual $1-\mathrm{km}^{2}$ cells, stem $\mathrm{C}$ averaged $15 \mathrm{~kg} \mathrm{C} \mathrm{m}^{-2} \quad$ (Fig. 3a), NPP averaged $0.90 \mathrm{~kg} \mathrm{C} \mathrm{m}^{-2} \mathrm{yr}^{-1}$ (Fig. 3b), and NEP averaged $0.25 \mathrm{~kg} \mathrm{C} \mathrm{m}^{-2} \mathrm{yr}^{-1}$ (Fig. 3c) over the MCI region.

\subsection{Harvest}

The seven management scenarios removed from 0.05 to $0.16 \mathrm{~kg} \mathrm{C} \mathrm{m}^{-2} \mathrm{yr}^{-1}$, or 11 to $3810^{6} \mathrm{t} \mathrm{C} \mathrm{yr}^{-1}$ for the MCI region. In general, annual harvest removal was steady or increased over the simulation period (Fig. 4a), as average C content increased (see below). The observed decline in the $\mathrm{AH}$ scenario resulted from harvesting the older stands with higher $C$ content in roughly 20 years, at which time the harvest of younger stands 

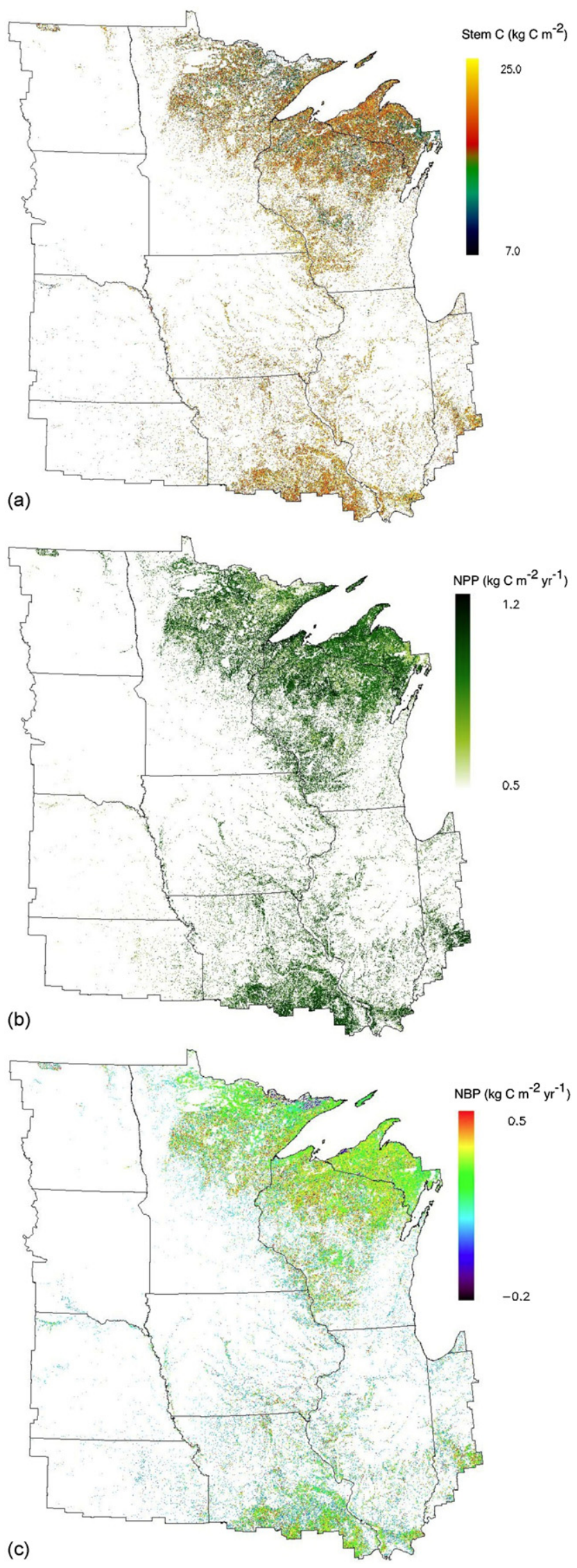

Fig. 3 - Model results of aboveground vegetation C (a), NPP (b), and NBP (c) in for the MCI region in 2004.
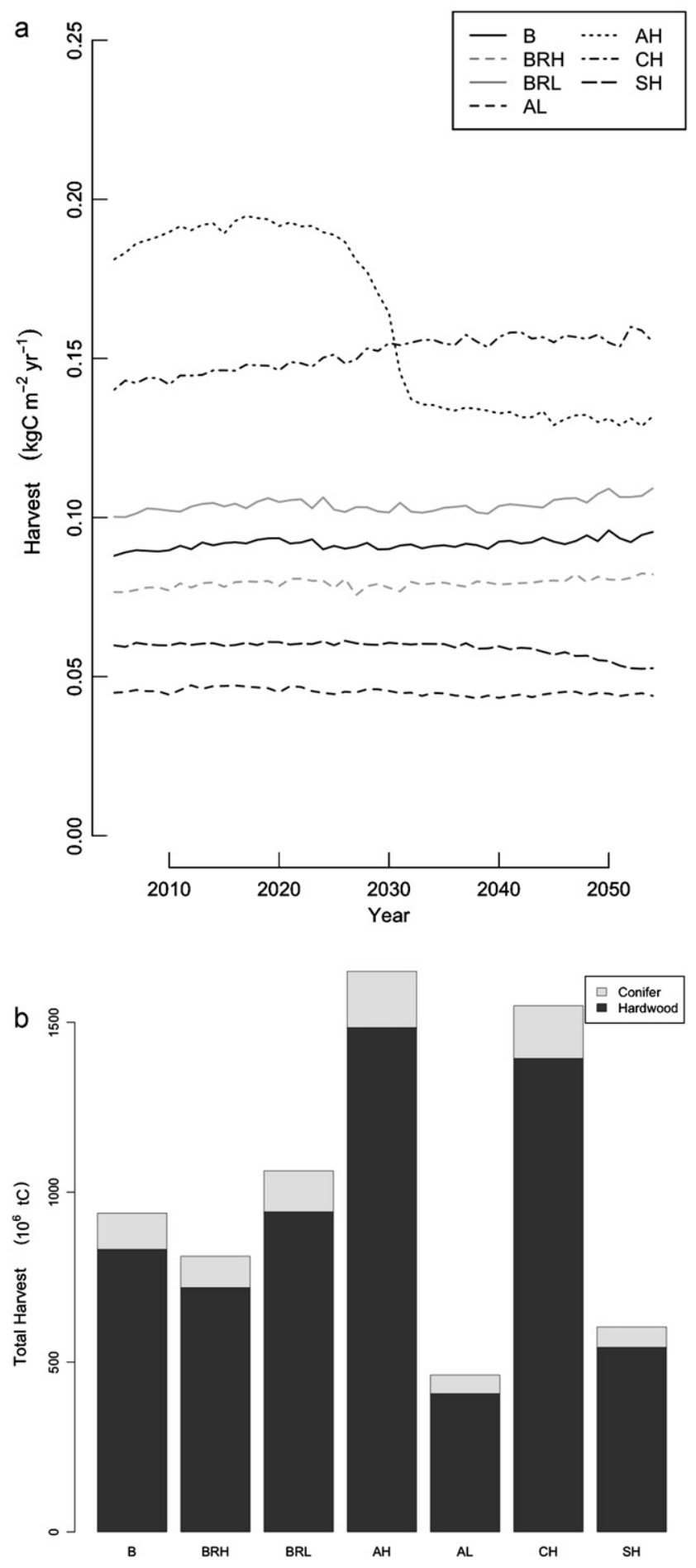

Fig. 4 - Model results of harvested C for the seven management scenarios, annual harvest where each denoted by a different line type (a) and the total harvest over the 50 years (b).

( $<60 \mathrm{yr}$ ) with lower biomass was required to meet the prescribed area harvest target. Both the AL and SH scenarios maintained relatively constant harvest throughout the simulation (Fig. 4a). The $\mathrm{AH}$ and $\mathrm{AL}$ scenarios yielded the greatest and lowest total harvest output, respectively, (Fig. 4b). Fig. 4a showed slight temporal trends in harvest under the $\mathrm{B}, \mathrm{BRH}$, 
$\mathrm{BRL}$, and $\mathrm{CH}$ scenarios. We speculate the observed trends are due to the constraints we used in selecting harvest sites. Had every grid cell been available at random, regardless of when it was last harvested, the harvest amounts would likely be nearly constant.

\subsection{Stand structure}

Time since last harvest (a proxy for stand age) changed dramatically (from initial condition) in all scenarios over the 50-year simulation (Fig. 5). The base or business as usual conditions, the BRH, and BRL scenarios increased the number of young ( $<50$ years) and decreased the number of middleaged and mature stands ( $>100$ years), although all there were nearly identical at simulation end. The $\mathrm{SH}$ and $\mathrm{CH}$ scenarios increased the number of young stands by as much as $200 \%$ and decreased the number of mature stands. The AH scenario doubled the number of younger stands compared to the other scenarios, and decreased the number of stands $>50$ years old. The AL scenario changed stand structure the least compared to the base scenario.

\subsection{Vegetation carbon}

Total (above + belowground) vegC content increased and decreased for the MCI region, depending upon harvest scenario; however, the harvest scenario had a similar effect on vegC, regardless of forest type (Figs. 6a-8a). For hardwood forests, the SH and AL scenarios increased vegC by 25 and $29 \%$, respectively, while the $\mathrm{CH}$ and $\mathrm{AH}$ scenarios decreased vegC by 8 and $9 \%$, respectively, during the 50 years (Fig. 7a). In conifer forests, the $\mathrm{SH}$ and AL scenarios increased vegC by 37 and $42 \%$, respectively, while the $\mathrm{CH}$ and $\mathrm{AH}$ scenarios decreased vegC by 12 and 13\%, respectively (Fig. 8a).

\subsection{Net primary production}

In general, all harvest scenarios decreased NPP for the MCI region (Fig. 6b) over the simulation period. The $\mathrm{AH}$ and $\mathrm{CH}$ scenarios had the lowest mean NPP, $0.79 \mathrm{~kg} \mathrm{C} \mathrm{m}^{-2} \mathrm{yr}^{-1}$, while the AL and $\mathrm{SH}$ had the highest mean NPP of $0.83 \mathrm{~kg} \mathrm{C} \mathrm{m}^{-2} \mathrm{yr}^{-1}$. NPP for the $B$ scenario averaged $0.81 \mathrm{~kg} \mathrm{C} \mathrm{m}^{-2} \mathrm{yr}^{-1}$. On average, the harvest scenarios changed NPP by $<3 \%$ for the 50 -year simulation period, but the more intensive harvest scenarios (AH and $\mathrm{CH}$ ) decreased NPP while less intensive harvest scenarios (SH and $\mathrm{AL}$ ) increased NPP when compared to the base (B) scenario. The BRH, or the treatment with high residue retention, decreased NPP by $13 \%$, or $13310^{6} \mathrm{t} \mathrm{C}$, over the entire 50-year period. NPP trends for hardwood forests mirrored the overall pattern for the MCI region because hardwoods are the dominant forest cover type (Fig. 7b). NPP varied the greatest for the AH scenario where NPP decreased by as much as $14 \%$, in the early years but recovered to within $9 \%$ of the initial NPP. We speculate that this pattern is due to the large number of stands (compared to pre-2004) harvested in the early years of the simulation period reaching maximum NPP. Depending on the harvest scenario, NPP increased and decreased for conifer forests (Fig. 8b). Relative to the base

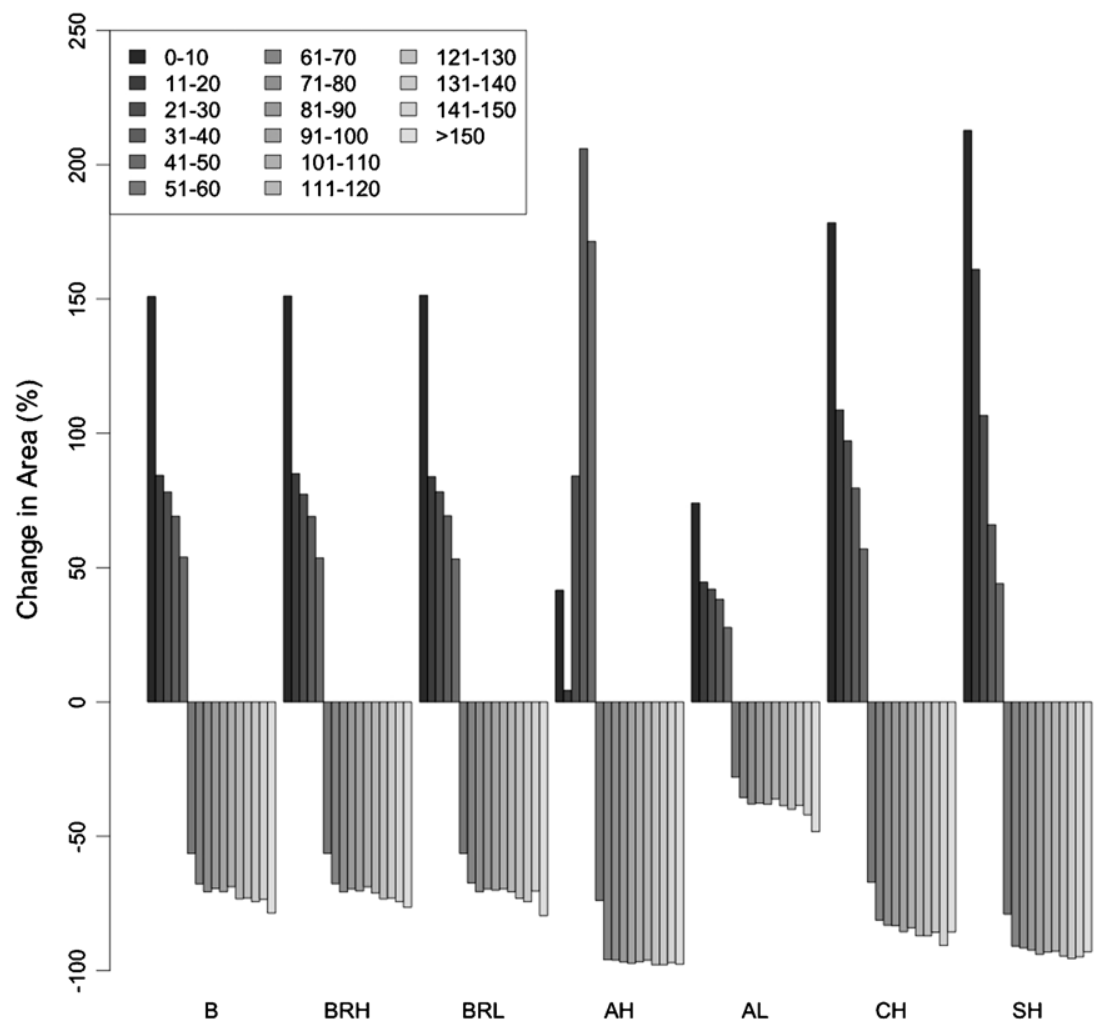

Fig. 5 - Change in simulated stand age structure (time since disturbance) between simulation start and end for the seven management scenarios. Each vertical bar represents the area change in a 10-year age class. 


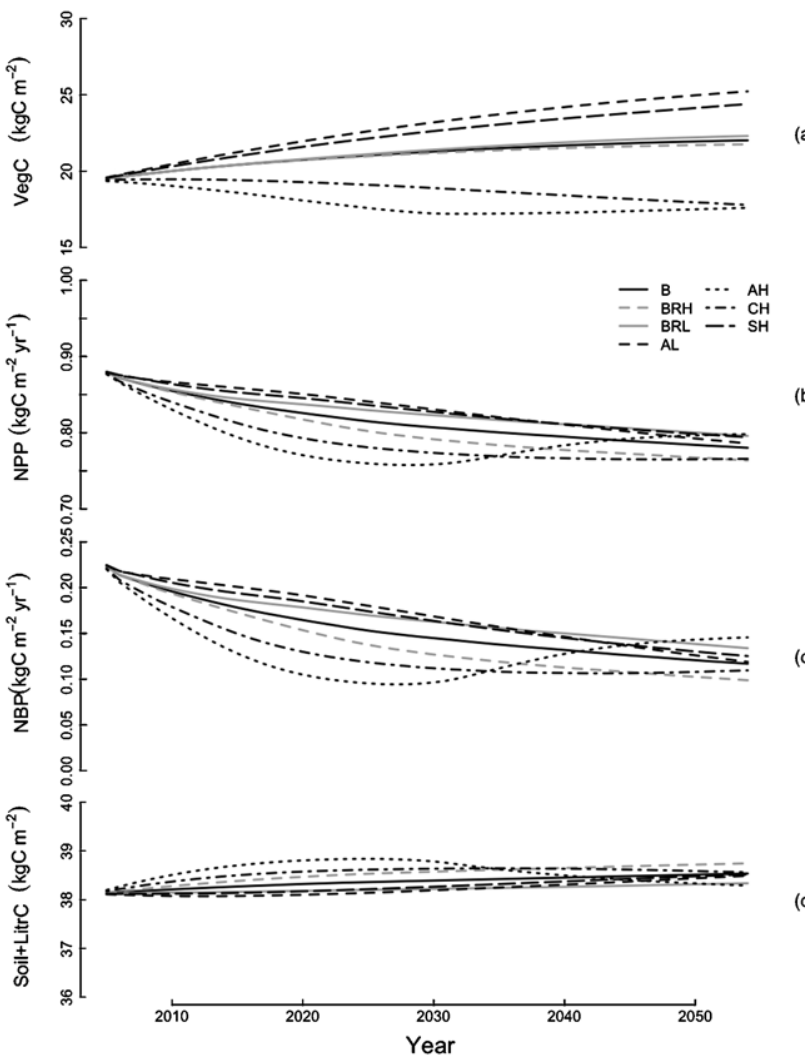

Fig. 6 - Model results of vegetation C (a), net primary production (b), and net biome production (c) for the forests of the MCI region. Results of the different management scenarios are denoted with differing line type.

scenario, the SH and AL scenarios increased NPP by 3 and $4 \%$, respectively, while the $\mathrm{CH}$ scenario decreased mean NPP by $4 \%$.

\subsection{Net biome production}

NBP, or the sum of NEP for all forests, for the MCI region declined over the simulation period for all scenarios (Fig. 6c). During the first 25 years, NBP decreased the greatest for the $\mathrm{AH}$ (57\%) and $\mathrm{CH}$ (49\%) scenarios, but remained constant or increased in the final 25 years. Conversely, NBP was greatest for the SH and AL scenarios during the first 25 years. The BRL scenario had the greatest NBP of all the residue removal scenarios. NBP patterns for hardwood forests resembled the overall MCI region because hardwood forests comprised about $80 \%$ of the simulated forested area (Fig. 7c). NBP decreased by $58 \%$ and $50 \%$ during the first 25 years for the $\mathrm{AH}$ and $\mathrm{CH}$ scenarios, respectively; however, the NBP for the AH scenario recovered to within $35 \%$ of its initial value by year 50 . NBP varied less, and was consistently lower for conifers than hardwoods (Fig. 8c). AH and CH decreased by 58 and $50 \%$ in the first 25 years, respectively, but increased to within 40 and $54 \%$ of their starting value by 50 years, following the trend in NPP described above. The SH and AL scenarios had nearly constant NBP for the first 15 years, and slowly declined thereafter.

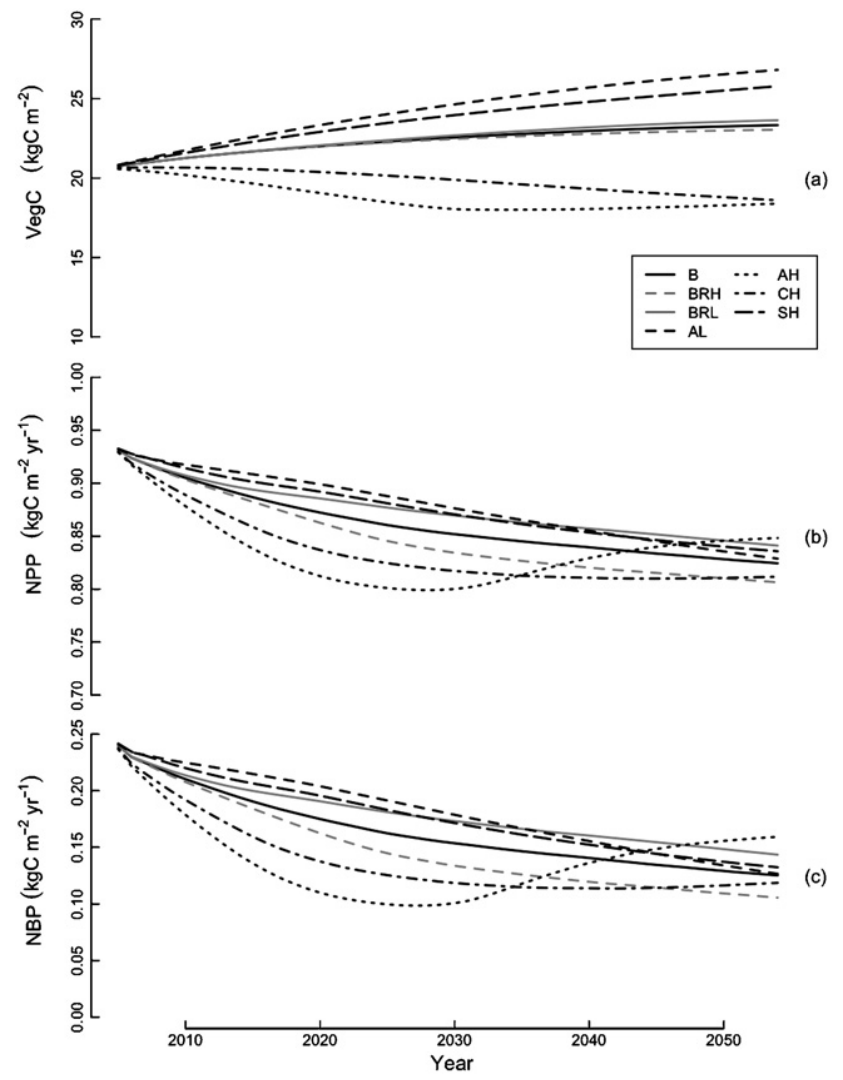

Fig. 7 - Model results of vegetation C (a), net primary production (b), and net biome production (c) for hardwood forests of the MCI region. Results of the different management scenarios are denoted with differing line type.

\subsection{Soil and litter carbon}

Soil and litter carbon (including woody debris) generally increased slightly for all harvest scenarios in the MCI region (Fig. 6d). Increasing residue removal decreased soil and litter $C$ accumulation (BRH vs. BRL) by $1 \%$. Soil and litter accumulation rates ranged from $0.002 \mathrm{~kg} \mathrm{C} \mathrm{m}^{-2} \mathrm{yr}^{-1}$, to $0.012 \mathrm{~kg} \mathrm{C} \mathrm{m}^{-2} \mathrm{yr}^{-1}$ for the $\mathrm{AH}$ and $\mathrm{BRH}$ scenarios, respectively.

\section{Discussion}

The renewed interest in woody biomass bioenergy (Perlack et al., 2005) has prompted forest managers, policy makers, and ecologists to elucidate the trade-offs of using forests for carbon storage, carbon sequestration, biodiversity, and feedstock for bioenergy. The purpose of this study was to explore the effects of different harvest scenarios on regional forest $\mathrm{C}$ dynamics. Most regional to national forest modeling studies do not account for the direct effects of harvest (i.e. resetting succession and its implication on forest carbon budgets) or the indirect effects of harvest (i.e. nutrient removal and its feedbacks of forest productivity). In other words, the forest landscape is treated as a static entity. Yet, all the major processes that define net $C$ exchange between the forest and 


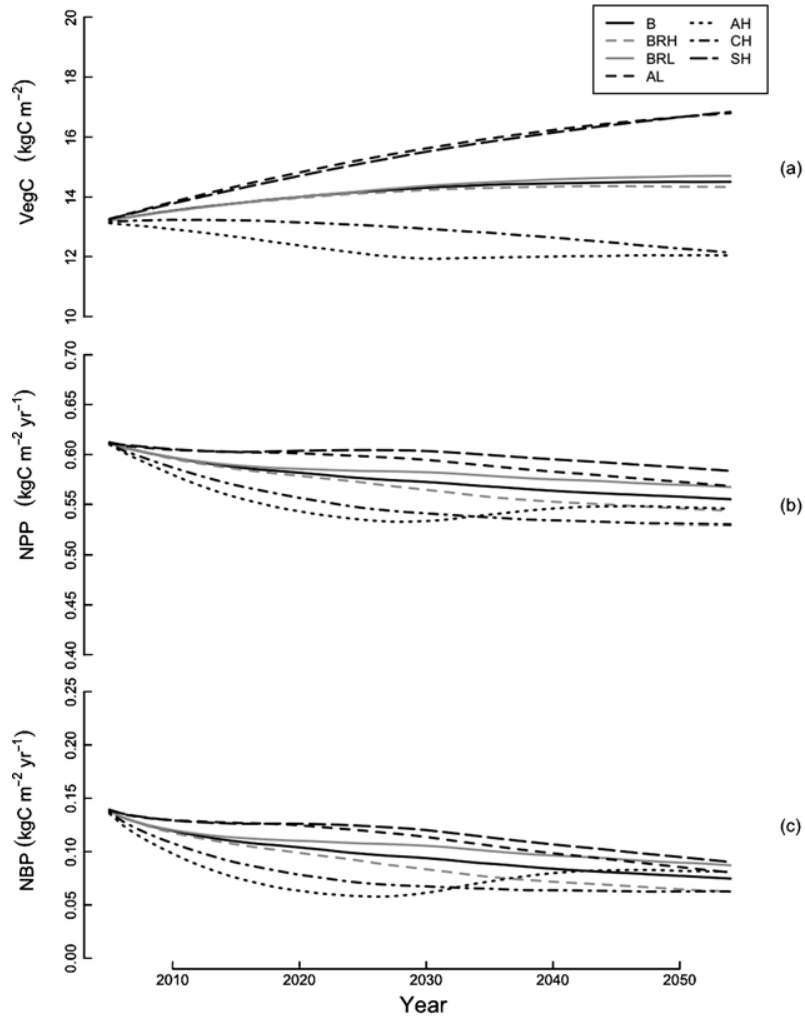

Fig. 8 - Model results of vegetation C (a), net primary production (b), and net biome production (c) for conifer forests of the MCI region. Results of the different management scenarios are denoted with differing line type.

atmosphere are stand age and disturbance dependent (Gower, 2003). That said, there are numerous complexities that need improvement to refine regional to global forest $C$ budget estimates and develop comprehensive sustainable forest management plans. We believe this is the first ever attempt to elucidate some of the trade-offs of different forest harvest scenarios on key ecosystem services of carbon storage and carbon sequestration at this scale.

This study utilized numerous spatial data sets to parameterize and initialize Biome-BGC. Two important attributes of the spatial data layers were disturbance history and current stand age. Forest NBP is strongly dependent on stand age structure (Alexandrov et al., 1999; Euskirchen et al., 2002; Bond-Lamberty et al., 2006; Amiro et al., 2010), and hence our estimates rely on both the accuracy of the model processes and the input data. We utilized the most comprehensive data available for stand age structure at a multi-state scale and utilized the recently released Landsat satellite record to help derive the harvest rates in the seven management scenarios. As knowledge and analysis of the extent, timing, and intensity of forest disturbance increases, further improvements can be made to ecosystem $C$ flux estimates using process-based models.

\subsection{Implications of increased harvest residue removal}

Varying the harvest residue left on site had significant effects on simulated NPP and NBP (Figs. 6-9). The scenarios where harvest residues were varied resulted in a wide range of total NBP, but had relatively little impact on aboveground C content (Fig. 9) in the 50-year period. Both residue quantity and quality influence soil carbon and nitrogen dynamics, and nitrogen availability influences NPP (Landsberg and Gower, 1997; Peckham and Gower, 2011). Relative to the base (B) scenario, the BRH scenario decreased NPP and NBP for both hardwood and conifer forest types, while BRL increased NPP and NBP for both forest types for the relatively short 50-year simulation period. We speculate the results are explained by the effects of coarse woody debris on decomposition and nitrogen mineralization. Biome-BGC logic allows for plants and microbes to compete for available $\mathrm{N}$, so lower retention of coarse woody harvest residue reduces the input of detritus with high C:N ratio. As a result, more $\mathrm{N}$ is available for plant growth (i.e. higher NPP). However, it is important to note that this trend is short-lived or transient, because multiple-harvests of high intensity reduce available $\mathrm{N}$ and soil $\mathrm{C}$ accumulation, and lead to decreased NPP. Peckham and Gower (2011), using BiomeBGC, reported that low coarse woody harvest residue retention initially increased NPP and NBP, but this pattern reversed after multiple harvest rotations decreased available nitrogen. Harvest residue retention affected NBP more than vegC or NPP (Figs. 6-9). The greater removal of $C$ and its impact on the forest $\mathrm{C}$ cycle warrants further study because of the great interest in harvest residue as a biofuel feedstock, but more importantly, the often unaccounted for effects of soil carbon disturbance on radiative forcing. Management activities that decrease soil $\mathrm{C}$ and increase atmospheric $\mathrm{CO}_{2}$ should be avoided because of the transfer of a "quasi-permanent" carbon pool (i.e. soil) to the atmosphere, and its long-term radiation forcing attributes. We note that this process is not captured in empirical forest growth models that do not simulate forest soil C dynamics.

\subsection{Forest response to changing harvest area and type}

Our simulations suggest that changes in the annual harvest area or harvest type (clear-cut vs. selective) dramatically affect regional C dynamics of the MCI region. In both hardwood and conifer forest types, doubling the area harvested (Table 4) or the proportion of clear-cut:selective harvest decreased both vegC and total NBP during the 50-year period (Figs. 9 and 10). Conversely, a $50 \%$ decrease in area harvested or proportion of clear-cut:selective harvest increased vegC and NBP (Figs. 9 and 10). These results are opposite of the pattern of increased harvest yielding increased NBP of the Chequamegon-Nicolet National Forest (CNNF), a sub-region of this study (Peckham et al., 2012). We speculate the opposite results can be explained by the difference in harvest area, average stand age, and the simulation length. Also, Peckham et al. (2012) used an optimization method to derive a harvest scenario that maximized NBP, but we did not use the optimization analysis in this study. Collectively, the two studies illustrate the influence of past and present harvest conditions on future regional $\mathrm{C}$ dynamics, the complexities of stand history that must be considered to maximize carbon sequestration, and the opportunities to increase $C$ sequestration of natural forests. We conclude the contrasting results of the two regions highlights the great need for more detailed analyses like this 


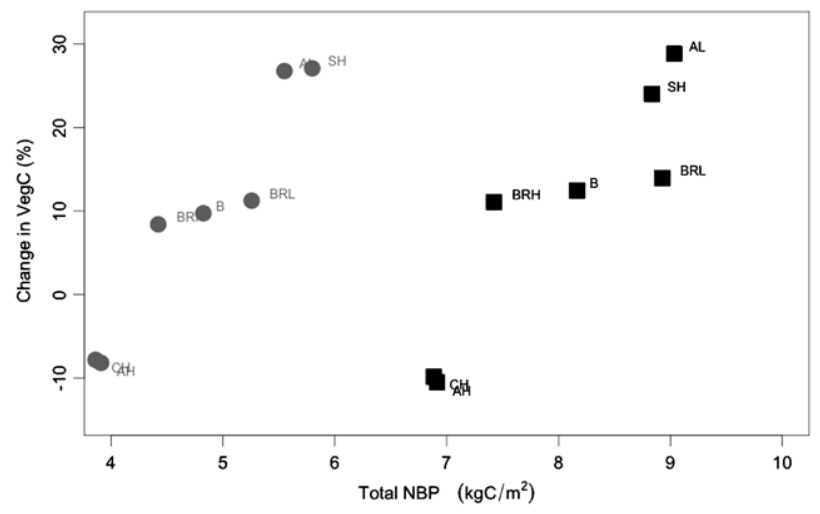

Fig. 9 - Change in vegetation carbon vs. total NBP over the 50-year simulation. Square symbols denote hardwood forest types, round symbols denote conifers. Each point is labeled with its management scenario.

study for other forest regions to better refine carbon management plans. Similar analyses are needed for other forest regions because (1) the forest stand structure differs among forest regions and (2) although NPP and NEP appear to follow a similar pattern for all forests, the rate of recovery and point of maximum NPP and NEP differ among forests (Gower et al., 1996; Ryan et al., 1997; Gower, 2003).

Changing harvest area and type also had significant effects on simulated stand structure. While both the $\mathrm{AL}$ and $\mathrm{SH}$ scenarios were very similar in NBP, NPP, vegC, and harvested C, their resulting stand structure were different (Fig. 5), and the $\mathrm{SH}$ scenario had a much higher proportion of recently harvested stands. We acknowledge the possibility that forest type (and hence structure) could change due to management practices in the 50-year period considered in this study, however Biome-BGC does not simulate conversion from one forest type to another. Carbon sequestration change due to a major change in species composition (i.e. one FIA forest type to another) is not captured in this study. One assumption in this study is that the forest type at each location remains constant.

Stand structure affects the diversity of numerous fauna groups, including insects (Summerville and Crist, 2002; Summerville, 2011), birds (DeGraaf et al., 1998, Robinson and Robinson, 1999), and small and large mammals (Verschuyl et al., 2011). This suggests that the dominant harvest type could have significant effects on biodiversity in the MCI region. Managing the MCI region for wood and paper products, carbon storage, and biodiversity are all critical components to sustainable forest management; optimizing one ecosystem good or service will likely have adverse effects on the others.

\subsection{Comparison to other studies}

Both our initialization and base simulations are consistent with other modeling studies. Lu and Zhuang (2010) used the Terrestrial Ecosystem Model in the Midwest U.S. (over a slightly larger area than the MCI covers) and reported Midwest forests were a C sink during 1948-2005, as was observed in the

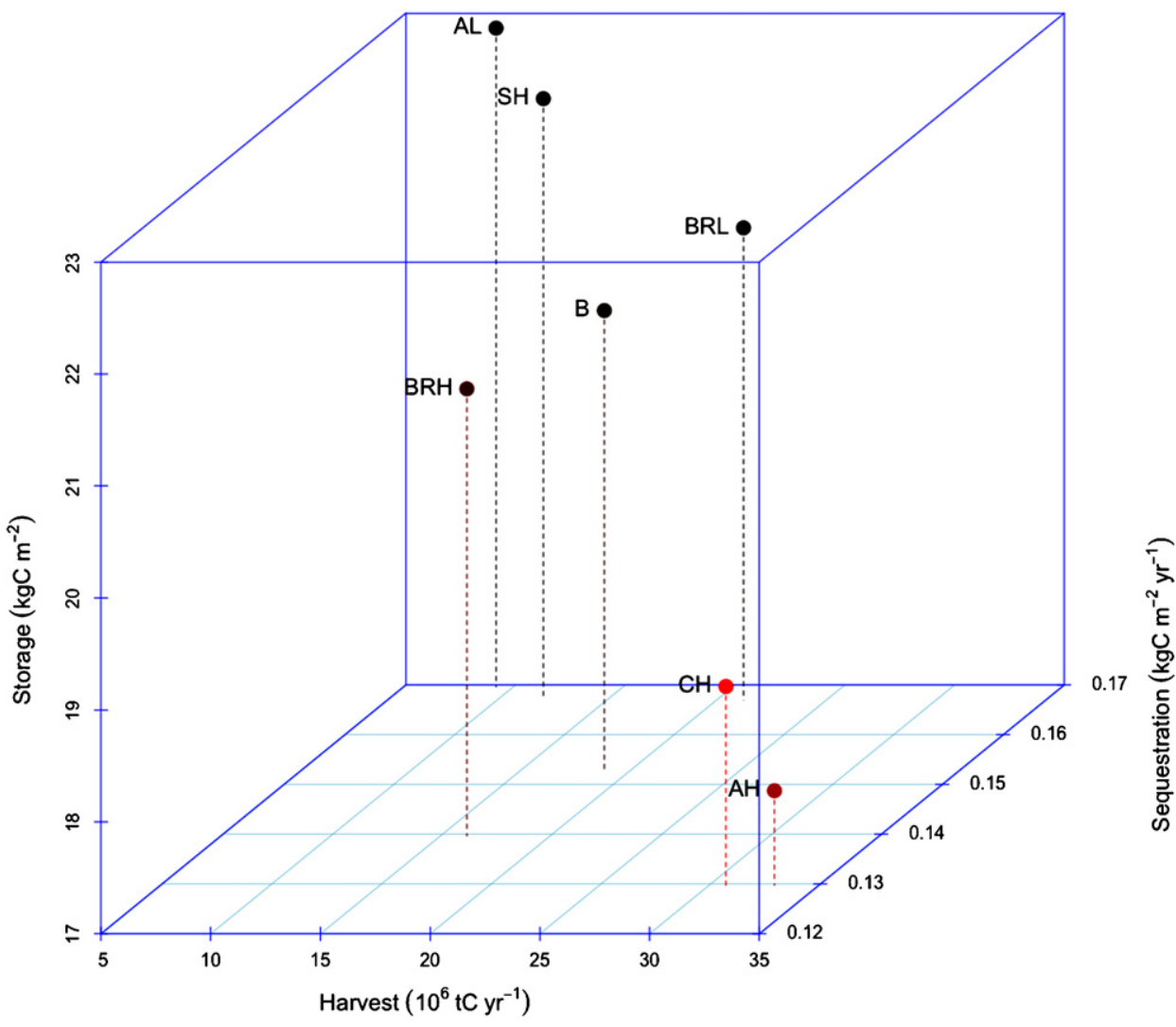

Fig. 10 - Three-dimensional scatterplot of carbon storage, carbon sequestration, and harvest for the seven management scenarios. Values on the $x, y$, and $z$ axes are annual averages. 
model initialization simulation in this study. Furthermore, Lu and Zhuang (2010) reported NPP increased by $2 \% \mathrm{yr}^{-1}$ from 1948 to 2008 and we reported NPP increased by $0.3 \% \mathrm{yr}^{-1}$ from 1948 to 2004 (data from initialization not shown). Our average NPP estimate was slightly higher, 850 vs. $700 \mathrm{~g} \mathrm{C} \mathrm{m}^{-2} \mathrm{yr}^{-1}$. We speculate that the discrepancy between the estimates of annual NPP increase and absolute NPP estimates between this study and Lu and Zhuang (2010) is attributed to the omission of age structure dynamics, and its effects on NPP (Gower et al., 1996; Ryan et al., 1997) and harvesting practices (Peckham and Gower, 2011) in the latter study. Potter et al. (2007) modeled NEP over the MCI region using remote sensing methods, and reported NEP varied between a source and a sink between 2001 and 2004, but they included agricultural as well as forest areas, therefore it is difficult to compare to results reported here.

The observed decline in NBP for both hardwood and conifers (Figs. 7c and 8c) is likely due to the increase in forest age, and its well-documented age-related NPP decline (Gower et al., 1996; Ryan et al., 1997). In most scenarios simulated here, $75 \%$ or more of the harvests removed only $25 \%$ of the biomass, therefore a larger percentage of forest reach maturity although harvest frequency is relatively high in the region. This general trend is consistent with Birdsey et al. (2006), who reported a decrease in future $\mathrm{C}$ sequestration over U.S. forests based on inventory data. They suggest that management practices could be implemented as a way to increase net $C$ uptake by the U.S. forest sector. The simulations in this study for the MCI region support their findings. Based on our study (Fig. 10), it is important to note again that $C$ management for storage versus sequestration may be at odds for some forests (Peckham et al., 2012).

\subsection{Implications of initialization process on observed $C$ fluxes}

As mentioned previously, Biome-BGC does not currently simulate landcover change or conversion, and land use change was an important process in the 1800s in the MCI region, especially in southern portions (Williams, 1989; Whitney, 1994). We simulated the disturbance history of only the present forested area in the MCI region to estimate current $C$ states and fluxes and to initialize the management scenarios. Detailed estimates of past $C$ fluxes due to harvest and landcover change in the U.S. have been published previously (Houghton and Hackler, 2000; Birdsey et al., 2006) and despite the different methodologies used, Houghton and Hackler (2000), Birdsey et al. (2006), and this study (i.e. data from 1800-2004 simulation) all concluded that the forest $C$ flux in the region changed from a source to a sink around the middle of the 20th century. This suggests that our simulated disturbance history agrees temporally with previous works (Houghton and Hackler, 2000; Birdsey et al., 2006; Lu and Zhuang, 2010), as well as patterns outlined in historical accounts (Williams, 1989; Whitney, 1994; Frelich, 1995; Steyaert and Knox, 2008).

In general, NPP declined for all management scenarios (Figs. 6b-8b) over the 50-year period, following the trend in NBP. In most scenarios, C storage increased slightly as NPP exceeded harvest. The initialization procedure used here was designed produce an unbiased estimate of $\mathrm{C}$ and $\mathrm{N}$ states in 2004. We followed the general method outlined in previous modeling studies (Thornton et al., 2002; Hanson et al., 2004). Because disturbance data is not available for the entire study area post-1800, it is possible that the observed decline in NPP is due to an insufficient simulated disturbance in the 1800-2004 (logging, fire, clearing, etc.) period resulting in the majority of stands in states past peak (and hence declining) NPP. However, the general decline in NPP and C storage agrees with projections for the U.S. forests in Birdsey et al. (2006).

\subsection{Implications for $C$ management: $C$ storage versus $C$ sequestration}

The results from this study suggest that a reduction in harvest area and fraction of total harvest comprised of clear-cuts increased vegC and NBP (Fig. 10). Increasing the harvest area or clear-cut percentage by a factor of two would provide nearly three times the harvest compared to a reduction in these strategies, but would decrease total NBP by $30 \%$ (Fig. 10). Model simulations suggest increasing the amount of residue removed during harvest could provide additional biomass and also increase NBP in the MCI region (Figs. 9 and 10), while avoiding a decrease in aboveground $\mathrm{C}$ stocks. However, these results are specific to the MCI region as a whole, and may not be applicable to sub-regions or forest stands with different age structure and disturbance history. In a previous modeling study conducted for the Chequamegon-Nicolet National Forest, Peckham et al. (2012) reported that a slight increase in harvest area would maximize C sequestration over a 100year period. We believe the most unique, and important findings of this study are we clearly illustrate (1) both past and future harvest activities have a profound influence on regional forest $C$ dynamics, and (2) maximizing $C$ storage and $C$ sequestration are not mutually exclusive. There appears not to be one solution to managing for $\mathrm{C}$, either through sequestration, storage, or both. Each region (or spatial scale) is likely to have a unique set of conditions that should be considered. Continuing to develop data describing the timing, extent, and intensity of forest harvest, or any disturbance, will improve estimates of carbon uptake in Midwest forests.

\section{Conclusions}

Although less than $2 \%$ of the forests in the Upper Midwest region are harvested each year, these activities (e.g. harvest rate, harvest type, and the amount of residue retained) influence the regional forest $\mathrm{C}$ budget. Specifically, increasing the amount of clear-cut harvest or the area harvested reduced both NBP and vegC, especially in hardwood forest types. Varying the amount of harvest residue retention had a more profound effect on NBP than on vegetation C. Removing additional residue resulted in greater NBP over the 50-year period compared to the base simulation. Based on the results from this study, we strongly recommend that all future regional to national forest $\mathrm{C}$ modeling analyses account for past harvest history and incorporate probable harvest scenarios into their analyses. 


\section{Acknowledgments}

This research was supported by U.S. Department of Agriculture grant 00406117 to S.T. Gower and funding from the U.S. Forest Service and the U.S. Department of Energy funded Great Lakes Bioenergy Research Center. Sam Batzli assisted with preparation of spatial data.

\section{RE FERENCES}

Alexandrov, G.A., Yamagata, Y., Oikawa, T., 1999. Towards a model for projecting Net Ecosystem Production of the world forests. Ecological Modelling 123, 183-191.

Amiro, B.D., Barr, A.G., Barr, J.G., Black, T.A., Bracho, R., Brown, M., Chen, J., Clark, K.L., Davis, K.J., Desai, A.R., Dore, S., Engel, V., Fuentes, J.D., Goldstein, A.H., Goulden, M.L., Kolb, T.E., Lavigne, M.B., Law, B.E., Margolis, H.A., Martin, T., McCaughey, J.H., Misson, L., Montes-Helu, M., Noormets, A. Randerson, J.T., Starr, G., Xiao, J., 2010. Ecosystem carbon dioxide fluxes after disturbance in forests of North America. Journal of Geophysical Research - Biogeoscience 115.

Birdsey, R., Pregitzer, K., Lucier, A., 2006. Forest carbon management in the United States: 1600-2100. Journal of Environmental Quality 35, 1461-1469.

Bond-Lamberty, B., Gower, S.T., Ahl, D.E., 2007a. Improved simulation of poorly drained forests using Biome-BGC. Tree Physiology 27, 703-715.

Bond-Lamberty, B., Gower, S.T., Goulden, M.L., McMillan, A., 2006. Simulation of boreal black spruce chronosequences: comparison to field measurements and model evaluation. Journal of Geophysical Research - Biogeoscience 111.

Bond-Lamberty, B., Peckham, S.D., Ahl, D.E., Gower, S.T., 2007 b. Fire as the dominant driver of central Canadian boreal forest carbon balance. Nature 450, 89-92.

Bond-Lamberty, B., Peckham, S.D., Gower, S.T., Ewers, B.E., 2009. Effects of fire on regional evapotranspiration in the central Canadian boreal forest. Global Change Biology 15, 1242-1254.

Chapin, F.S., Woodwell, G.M., Randerson, J.T., Rastetter, E.B., Lovett, G.M., Baldocchi, D.D., Clark, D.A., Harmon, M.E., Schimel, D.S., Valentini, R., Wirth, C., Aber, J.D., Cole, J.J., Goulden, M.L., Harden, J.W., Heimann, M., Howarth, R.W., Matson, P.A., McGuire, A.D., Melillo, J.M., Mooney, H.A., Neff, J.C., Houghton, R.A., Pace, M.L., Ryan, M.G., Running, S.W., Sala, O.E., Schlesinger, W.H., Schulze, E.D., 2006. Reconciling carbon-cycle concepts, terminology, and methods. Ecosystems 9, 1041-1050.

Cleland, D.T., Crow, T.R., Saunders, S.C., Dickmann, D.I., Maclean, A.L., Jordan, J.K., Watson, R.L., Sloan, A.M., Brosofske, K.D., 2004. Characterizing historical and modern fire regimes in Michigan (USA): a landscape ecosystem approach. Landscape Ecology 19, 311-325.

Crevoisier, C., Sweeney, C., Gloor, M., Sarmiento, J.L., Tans, P.P., 2010. Regional US carbon sinks from three-dimensional atmospheric $\mathrm{CO}_{2}$ sampling. Proc. Natl. Acad. Sci. U.S.A. 107, 18348-18353.

DeGraaf, R.M., Hestbeck, J.B., Yamasaki, M., 1998. Associations between breeding bird abundance and stand structure in the White Mountains, New Hampshire and Maine, USA. Forest Ecology and Management 103, 217-233.

Etheridge, D.M., Steele, L.P., Langenfelds, R.L., Francey, R.J., Barnola, J.-M., Morgan, V.I., 1998. Historical $\mathrm{CO}_{2}$ records from the Law Dome DE08, DE08-2, and DSS ice cores. In: Trends: A Compendium of Data on Global Change, Oak Ridge National Laboratory, U.S. Department of Energy, Oak Ridge, TN.
Euskirchen, E.S., Chen, J.Q., Li, H.B., Gustafson, E.J., Crow, T.R., 2002. Modeling landscape net ecosystem productivity (LandNEP) under alternative management regimes. Ecological Modelling 154, 75-91.

Farquhar, G.D., Caemmerer, S.V., Berry, J.A., 1980. A biochemical-model of photosynthetic $\mathrm{CO}_{2}$ assimilation in leaves of C-3 species. Planta 149, 78-90.

Frelich, L.E., 1995. Old Forest in the Lake States Today and before European Settlement. National Areas Journal 15, 157167.

Goodale, C.L., Apps, M.J., Birdsey, R.A., Field, C.B., Heath, L.S., Houghton, R.A., Jenkins, J.C., Kohlmaier, G.H., Kurz, W., Liu, S.R., Nabuurs, G.J., Nilsson, S., Shvidenko, A.Z., 2002. Forest carbon sinks in the Northern Hemisphere. Ecological Applications 12, 891-899.

Gower, S.T., 2003. Patterns and mechanisms of the forest carbon cycle. Annual Review of Environment and Resources 28, 169204.

Gower, S.T., McMurtrie, R.E., Murty, D., 1996. Aboveground net primary production decline with stand age: potential causes. Trends in Ecology \& Evolution 11, 378-382.

Gronewold, C.A., D'Amato, A.W., Palik, B.J., 2010. The influence of cutting cycle and stocking level on the structure and composition of managed old-growth northern hardwoods. Forest Ecology and Management 259, 1151-1160.

Hanson, P.J., Amthor, J.S., Wullschleger, S.D., Wilson, K.B., Grant, R.F., Hartley, A., Hui, D., Hunt, E.R., Johnson, D.W., Kimball, J.S., King, A.W., Luo, Y., McNulty, S.G., Sun, G., Thornton, P.E., Wang, S., Williams, M., Baldocchi, D.D., Cushman, R.M., 2004. Oak forest carbon and water simulations: model intercomparisons and evaluations against independent data. Ecological Monographs 74, 443489.

Houghton, R.A., Hackler, J.L., 2000. Changes in terrestrial carbon storage in the United States. 1: the roles of agriculture and forestry. Global Ecology and Biogeography 9, 125-144.

Kimball, J.S., Thornton, P.E., White, M.A., Running, S.W., 1997. Simulating forest productivity and surface-atmosphere carbon exchange in the BOREAS study region. Tree Physiology 17, 589-599.

Landsberg, J.J., Gower, S.T., 1997. Applications of Physiological Ecology to Forest Management. Academic Press, Inc., San Diego.

Law, B.E., Turner, D., Campbell, J., Sun, O.J., Van Tuyl, S., Ritts, W.D., Cohen, W.B., 2004. Disturbance and climate effects on carbon stocks and fluxes across Western Oregon USA. Global Change Biology 10, 1429-1444.

Lu, X.L., Zhuang, Q.L., 2010. Evaluating climate impacts on carbon balance of the terrestrial ecosystems in the Midwest of the United States with a process-based ecosystem model. Mitigation and Adaptation Strategies for Global Change 15, 467-487.

Peckham, S.D., Gower, S.T., 2011. Simulated long-term effects of harvest and biomass residue removal on soil carbon and nitrogen content and productivity for two Upper Great Lakes forest ecosystems. Global Change Biology Bioenergy 3, 135147.

Peckham, S.D., Gower, S.T. Simulating the effects of harvest and biofuel production on the forest system carbon balance of the Midwest, USA. Global Change Biology Bioenergy. Accepted.

Peckham, S.D., Gower, S.T., Buongiorno, J., 2012. Estimating the carbon budget and maximizing future carbon uptake for a temperate forest region in the U.S. Carbon balance and management 7, 6 DOI:10.1186/1750-0680-7-6.

Perlack, R.D., Wright, L.L., Turhollow, A.F., Graham, R.L., Stokes, B.J., Erbach, D.C., 2005. Biomass as Feedstock for a Bioenergy and Bioproducts Industry: The Technical Feasibility of a 
Billion-ton Annual Supply. U.S. Department of Energy and U.S. Department of Agriculture, USA.

Potter, C., Klooster, S., Huete, A., Genovese, V., 2007. Terrestrial carbon sinks for the United States predicted from MODIS satellite data and ecosystem modeling. Earth Interactions 11

Robinson, W.D., Robinson, S.K., 1999. Effects of selective logging on forest bird populations in a fragmented landscape. Conservation Biology 13, 58-66.

Running, S.W., Coughlan, J.C., 1988. A general-model of forest ecosystem processes for regional applications. I. Hydrologic balance, canopy gas-exchange and primary production processes. Ecological Modelling 42, 125-154.

Running, S.W., Gower, S.T., 1991. Forest-BGC, a general-model of forest ecosystem processes for regional applications. II. Dynamic carbon allocation and nitrogen budgets. Tree Physiology 9, 147-160.

Ryan, M.G., Binkley, D., Fownes, J.H., 1997. Age-related decline in forest productivity: pattern and process. Advances in Ecological Research 27, 213-262.

Ryan, M.G., Harmon, M.E., Birdsey, R.A., Giardina, C.P., Heath, L.S., Houghton, R.A., Jackson, R.B., McKinley, D.C., Morrison, J.F., Murray, B.C., Pataki, D.E., Skog, K.E., 2010. A Synthesis of the science on forests and carbon for U.S. forests. Issues in Ecology 13, 1-16.

Smith, J.E., Heath, L.S., Woodbury, P.B., 2004. How to estimate forest carbon for large areas from inventory data. J. For. 102, 25-31.

Smith, W.B., Miles, P.D., Perry, C.H., Pugh, S.A., 2010. Forest Resources of the United States, 2007. U.S. Department of Agriculture, Forest Service, Washington, D.C.

Steyaert, L.T., Knox, R.G., 2008. Reconstructed historical land cover and biophysical parameters for studies of landatmosphere interactions within the eastern United States. Journal of Geophysical Research - Atmosphere 113.

Stueve, K.M., Housman, I.W., Zimmerman, P.L., Nelson, M.D., Webb, J.B., Perry, C.H., Chastain, R.A., Gormanson, D.D., Huang, C., Healey, S.P., Cohen, W.B., 2011. Snow-covered Landsat time series stacks improve automated disturbance mapping accuracy in forested landscapes. Remote Sensing of Environment 115 (12), 3203-3219.

Summerville, K.S., 2011. Managing the forest for more than the trees: effects of experimental timber harvest on forest Lepidoptera. Ecological Applications 21, 806-816.

Summerville, K.S., Crist, T.O., 2002. Effects of timber harvest on forest Lepidoptera: Community, guild, and species responses. Ecological Applications 12, 820-835.

Thornton, P.E., Rosenbloom, N.A., 2005. Ecosystem model spinup: Estimating steady state conditions in a coupled terrestrial carbon and nitrogen cycle model. Ecological Modelling 189, 25-48.

Thornton, P.E., Law, B.E., Gholz, H.L., Clark, K.L., Falge, E., Ellsworth, D.S., Golstein, A.H., Monson, R.K., Hollinger, D., Falk, M., Chen, J., Sparks, J.P., 2002. Modeling and measuring the effects of disturbance history and climate on carbon and water budgets in evergreen needleleaf forests. Agricultural and Forest Meteorology 113, 185-222.

United States Department of Agriculture, Forest Service, 2001. United States Timber Industry - An Assessment of Timber Product Output and Use, 1996. General Technical Report SRS-045. United States Department of Agriculture, Forest Service, Asheville, NC, pp. 154.

Verschuyl, J., Riffell, S., Miller, D., Wigley, T.B., 2011. Biodiversity response to intensive biomass production from forest thinning in North American forests - a meta-analysis. Forest Ecology and Management 261, 221-232.

Wang, W.L., Dungan, J., Hashimoto, H., Michaelis, A.R., Milesi, C., Ichii, K., Nemani, R.R., 2011. Diagnosing and assessing uncertainties of terrestrial ecosystem models in a multimodel ensemble experiment: 2. Carbon balance. Global Change Biology 17, 1367-1378.

White, M.A., Thornton, P.E., Running, S.W., Nemani, R.R., 2000. Parameterization and sensitivity analysis of the Biome-BGC terrestrial ecosystem process model: net primary production controls. Earth Interactions 4, 1-85.

Whitney, G.G., 1994. From coastal wilderness to fruited plain: a history of environmental change in temperate North America, 1500 to the present. Cambridge University Press, UK.

Williams, M., 1989. Americans and their Forests: a Historical Geography. Cambridge University Press, UK.

Wilson, B.T., Lister, A.J., Riemann, R.I., Griffith, D.M., 2009ongoing. A moderate resolution nearest-neighbor imputation dataset of the continental United States for large area mapping of forest characteristics using field sampled data. Northern Research Station, USDA Forest Service, St. Paul, Minnesota.

Scott D. Peckham is an Honorary Associate Fellow at the University of Wisconsin-Madison. His primary research interests lie in using process-based models to simulate the forest and industrial ecosystem carbon cycles at various spatial scales and to estimate the long-term effects of biomass harvest on soil carbon and nitrogen and productivity, carbon sequestration and storage potential, and the impacts of management and forest product production on net forest carbon balance over large regions. He is currently a post-doctoral research associate at the University of Wyoming.

Stith T. Gower is Professor of Forest Ecology at the University of Wisconsin-Madison. His research interests include studying the effects of disturbance on forest ecosystem structure and function, regionalization of carbon, water and nutrient budgets for terrestrial ecosystems, biophysical controls on carbon assimilation and allocation in terrestrial ecosystems, nutrient circulation in natural and managed ecosystems, influences of natural and anthropogenic disturbances on soil carbon dynamics.

Charles H. (Hobie) Perry is a Research Soil Scientist with the USDA Forest Service. His research priorities include land cover change impacts on forested watersheds, forest soil carbon sequestration, linkages between soil properties and tree health, and accumulated toxics in soil (e.g., Hg). Prior to joining the Forest Service in 2004, he was Assistant Professor of wildland hydrology and watershed management in Humboldt State University's Department of Forestry and Wildland Resources. He holds an A.B. (magna cum laude) in Philosophy from the University of Michigan, and M.S. and Ph.D. degrees in Forestry from the University of Minnesota.

Barry (Ty) Wilson is a Research Forester with the USFS Northern Research Station Forest Inventory and Analysis program in Saint Paul, Minnesota. His research focuses on enhancing the utility of the program's field survey by integrating it with ancillary raster data sources, such as remote sensing imagery and digital elevation models, in an effort to construct better maps and estimates of the condition and extent of the forest resources of the United States.

Kirk Stueve is a landscape ecologist with expertise in using remote sensing and geographic information science to address research questions related to forest ecology. As a Research Ecologist with the USDA Forest Service between 2009 and 2011, he spearheaded the effort of adapting the vegetation change tracker algorithm for research pursuits regarding forest disturbance and regeneration in the Great Lakes. He is currently a Visiting Assistant Professor of Geography at North Dakota State University. 